\title{
Pierwsze dni stanu wojennego w Nowej Hucie
}

\author{
Piotr Kapusta \\ piotr.kapusta@uj.edu.pl
}

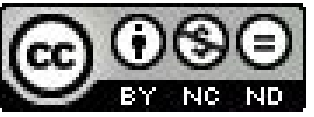

W 2011 r. obchodziliśmy trzydziestą rocznicę wprowadzenia stanu wojennego w Polsce. "Stan wojenny to sprawa nadal dla Polski aktualna", pisał Jan Rokita we wstępie do książki Wiesława Zabłockiego Stan wojenny w Małopolsce ${ }^{1}$. Wydarzenia te, stosunkowo nieodległe, ciągle znajdują się w świadomości wielu Polaków żyjących w tamtych czasach. Pamiętają o nich działacze opozycyjni, którzy niejednokrotnie byli internowani, oraz ich rodziny. Pamiętają o nich uczestnicy manifestacji, którzy za udział w nich płacili często swoim zdrowiem. Pamiętają wreszcie rodziny osób, które w latach 1981-1983 oraz po formalnym zniesieniu stanu wojennego (22 lipca 1983 r.) ginęły z powodów politycznych.

W niniejszej pracy przedstawilem przebieg pierwszych dni stanu wojennego w Kombinacie Huty im. Lenina w Nowej Hucie. W zamyśle jej twórców, Nowa Huta miała być osobnym, wzorowym miastem socjalistycznym, stała się jednak jednym z głównych, obok Gdańska, punktów oporu w kraju. Już w 1960 r. doszło w Nowej Hucie do wydarzeń określanych mianem „Walk o krzyż nowohucki" - nowohucianie zbuntowali się przeciwko cofnięciu zgody władz na wybudowanie pierwszego kościoła na terenie swojej dzielnicy. W 1979 r. miała miejsce próba „zamachu” na pomnik Włodzimierza Lenina znajdujący się w Alei Róż. Również strajk z 1988 r. udowodnił opozycyjny charakter „,najmłodszej siostry Krakowa” ${ }^{2}$, jak czasem określa się Nową Hutę.

\section{ZNACZENIE DATY 13 GRUDNIA 1981}

13 XII 1981 to jedna z najbardziej znaczących, symbolicznych i kontrowersyjnych ${ }^{3}$ dat historii Polskiej Rzeczpospolitej Ludowej. Tego dnia I sekretarz KC PZPR i zarazem premier Polski oraz minister obrony narodowej PRL gen. Wojciech Jaruzelski, nie czekając na uchwałę Rady Państwa ${ }^{4}$, ogłosił wprowadzenie stanu wojennego na terenie całego kraju. Rozpoczęły się akcje internowania działaczy „,Solidarności”, ${ }^{\prime \prime}$, wprowadzono godzinę milicyjna, wyłączono telefony ${ }^{6}$, zakazano opuszczania miejsca zamieszkania bez przepustki, pozamykano granice, stacje benzynowe i lotniska ${ }^{7}$, zawieszono wydawanie gazet ${ }^{8}$, ponieważ władze „,ograniczyły z konieczności

1 W. Zabłocki, Stan wojenny w Małopolsce, Kraków 1994, s. 6.

2 Taki tytuł miała wystawa plenerowa znajdująca się przed gmachem Nowohuckiego Centrum Kultury w $2009 \mathrm{r}$. Powstała z inicjatywy Adama Gryczyńskiego. http://www.jakiaparat.pl/najmlodsza_siostra_krakowa_druga_czesc_wystawy_plenerowej_poswieconej_nowej_hucie,1242423416,1, 26.04.2012.

Dyskusję nad koniecznością jego wprowadzenia w Polsce trwają do dziś. Obecnie historycy stoją na stanowisku, że w grudniu 1981 r. nie było realnego zagrożenia wkroczenia wojsk radzieckich do Polski. Podkreślają też nielegalność decyzji gen. Wojciecha Jaruzelskiego. Zgodnie z obowiązującą wówczas Konstytucją PRL z 22 VII 1952 Rada Państwa nie mogła wydawać dekretów w trakcie obrad Sejmu. W dniach 12-13 XII 1981 odbywała się sesja Sejmu.

4 A. Dudek, Z. Zblewski, Utopia nad Wista. Historia Peerelu, Warszawa - Bielsko-Biała 2008, s. 309.

5 Ludzie z Krakowa byli umieszczani w więzieniu karnym w Wiśniczu Nowym, a następnie kierowano ich m.in. do Załęża koło Rzeszowa, Uherec, Łupkowa, Jastrzębia. Zob. A. Chwalba, Dzieje Krakowa. Kraków w latach 1945-1989, t. 6., Kraków 2004, s. 408.

6 Łączność przywrócono dopiero w styczniu 1982 r. Każdy dzwoniący słyszał wówczas komunikat ostrzegawczy "rozmowa kontrolowana".

A. Chwalba, dz. cyt., s. 407.

8 "Głos Nowej Huty", na który będę się powoływał w pracy, nie ukazywał się przez cztery miesiące. W pierwszych numerze z roku 1982, który ukazał się 16 kwietnia możemy znaleźć artykuł Kalendarium 18 tygodni informujący o wydarzeniach w Nowej Hucie od połowy grudnia 1981 r. do połowy kwietnia 1982 r. 
konstytucyjny przywilej obywateli, powszechny dostęp do wszechstronnej komunikacji"9. Wyjątkami na poziomie centralnym były „Trybuna Ludu” - organ prasowy PZPR oraz „Żołnierz Wolności"10. Zawieszono wszystkie organizacje z wyjątkiem PZPR i podporządkowanych jej stronnictw politycznych, w tym także NSZZ Solidarność. Zaznaczmy, że jedyną rozwiązaną organizacją było Niezależne Zrzeszenie Studentów (5 I 1982) ${ }^{11}$.

Przygotowania do wprowadzenia stanu wojennego w naszym kraju trwały już od października 1980 r. ${ }^{12}$. Działacze Solidarności zdawali sobie z tego sprawę. Dla przykładu Zarząd Regionu Małopolska, pamiętając o doświadczeniach tzw. kryzysu bydgoskiego z marca 1981 r., wydał Instrukcję na wypadek wprowadzenia stanu wojennego ${ }^{13}$, która przewidywała strajk okupacyjny.

\section{POCZĄTKI STANU WOJENNEGO ${ }^{14}$}

Od początku grudnia $1981 \mathrm{r}$. sytuacja w całym kraju stawała się coraz bardziej napięta. Nie inaczej było na południu Polski. 1 XII 1981 r. ZOMO brutalnie pobiło wspótpracowników Zarządu Regionu Małopolska ${ }^{15}$. ZR chciał poinformować społeczeństwo o tym, co się stało, domagał się możliwości wystąpienia swoich przedstawicieli w telewizji. W przypadku braku spełnienia tego postulatu rozważano strajk ostrzegawczy. 12 XII $1981 \mathrm{r}$. „Głos Nowej Huty" opublikował artykuł zatytułowany Czy 14. XII będziemy strajkować w Małopolsce? ${ }^{16}$.

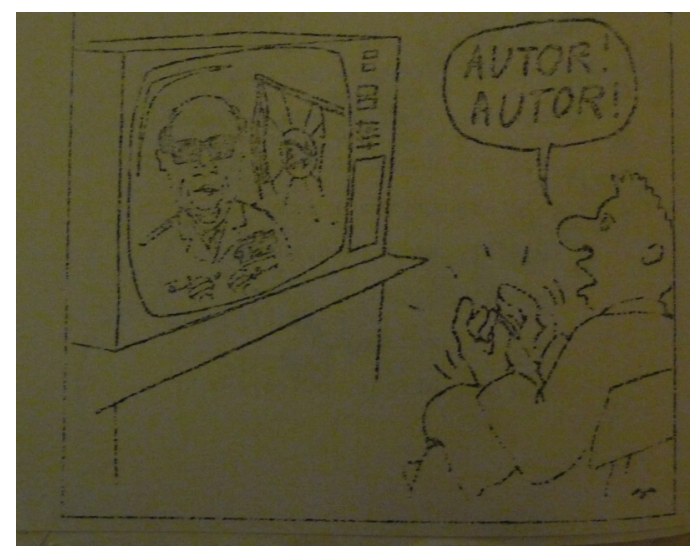

Można więc stwierdzić, że niektórzy spodziewali się wystąpień przeciw działalności władzy. Potwierdzają to słowa Jana Franczyka, który wprowadzenie stanu wojennego opisał w następujący sposób: „Z soboty na niedzielę wydarzyło się coś, coś jakby wisiało trochę w powietrzu, ale nikt do końca nie wierzył, że władze zdecydują się na tak drastyczny krok"17.

Maciej Mach ${ }^{18}$, inny działacz opozycyjny, także podkreślał: „W grudniu osiemdziesiątego

9 "Głos Nowej Huty" 1982, nr 1 (1303), s. 1.

10 http://histmag.org/?id=6200, 26.04.2012.

11 A. Gliksman, Solidarność Małopolska. Kalendarium 1980-2005, Kraków 2005, s. 76.

12 Sztab generalny zajął się jego przygotowywaniem już w październiku 1980 r., a 3 XI tego roku wiceminister spraw wewnętrznych gen. Bogusław Stachura wydał rozkaz do rozpoczęcia organizowania akcji pod kryptonimem „Wrzos”, która zakładała internowanie blisko 13 tys. osób. Zob. A. Dudek, Z. Zblewski, dz. cyt., s. 308.

13 W. Bukowski, Solidarność Małopolska w Podziemiu, Kraków 1991, s. 8.

14 Satyra stanu wojennego, Lublin 1983.

15 "Głos Nowej Huty” 1981, nr 50 (1302), s. 1.

16 Tamże.

17 Moja Nowa Huta. 1949-2009 wystawa jubileuszowa, Muzeum Historyczne Miasta Krakowa, Kraków 2009, s. 146.

18 Od września 1980 r. współtworzył struktury NSZZ Solidarność na Wydziale Blach Karoseryjnych (członek Komitetu Założycielskiego, a od marca 1981 r. Komisji Wydziałowej). Po ogłoszeniu stanu wojennego uczestniczył jako członek Komitetu Strajkowego w strajku hutników w Kombinacie (13 - 15 XII 1981 r.). Od stycznia 1982 r. wspóttworzył Komitet Ocalenia Solidarności oraz (od lata 1982 r.) tajną organizacię kierowniczą Grot. Po aresztowaniach członków obu organizacji jesienią 1982 r., współtworzył Tymczasową Komisję Robotniczą Hutników. Jednocześnie był wspótinicjatorem i współorganizatorem Społecznego Funduszu Pomocy Pracowniczej (źródło: relacja nagrana w dniach 12 i 20 X 2009 r.). 
pierwszego roku sytuacja była taka, że wszystko wskazywało na to, że coś się wydarzy (...) Od jakiegoś czasu było nagminne, że pod hutą przejeżdżały całe kolumny ZOMO, transportery, te budy, ileś tam, piętnaście, siedemnaście samochodów (...) Przewodniczący Komisji Zakładowej Solidarności z Akademii Medycznej dr Kutyba właśnie mówi, że na pewno coś się wydarzy ponieważ przyszło rozporządzenie żeby tych, których można wypisywać do domu aby było jak najwięcej wolnych łóżek. Ostrzegał i mówił, że w jego odczuciu jest to przygotowanie do jakiś rzeczy, które będą się działy. Natomiast samo wprowadzenie stanu wojennego było dla nas zaskoczeniem. Nikt się tego nie spodziewał. Ludzie by się trochę inaczej zachowali"19.

Zdecydowana większość społeczeństwa nie była jednak przygotowana na wprowadzenie stanu wojennego, który „spowodował szok nie tylko ludności naszego kraju, ale i głęboko wstrząsnął opinią publiczną świata"20 . Ludzie nagle znaleźli się w zupełnie innej sytuacji, często nie wiedzieli co działo się z internowanymi członkami ich rodzin bądź przyjaciółmi, wybuchały strajki ${ }^{21}$, dochodziło do walk ze służbami MO, ZOMO i ORMO oraz z wojskiem.

Jeden z opozycjonistów nowohuckich dwudziestotrzyletni wówczas Leszek Jaranowski22 wspominał po latach w 2009 r.: „Nie bardzo wiedzieliśmy co znaczy w ogóle stan wojenny. Większość ludzi nie wyobrażała sobie czym się to może skończyć. Raczej coś tam z lat poprzednich, szczególnie ludzie starsi mieli różne podejrzenia. Szczerze mówiąc była jedna wielka niewiadoma. Niemniej jednak każdy z nas czuł, że trzeba zaprotestować. W związku z tym zaprotestowaliśmy"23.

Powyższa wypowiedź świadczy, że ludzie kierowali się emocjami, że nie spodziewali się co ich może czekać. Z całą pewnością wiele osób obawiało się zbliżających się wydarzeń jednak Leszek Jaranowski wspominał, że tylko jeden człowiek z jego wydziału nie poparł strajkujących i wycofał się z tych działań.

Ogłoszenie stanu wojennego rozpoczęło proces internowania działaczy opozycyjnych na terenie całego kraju. Na mocy zarządzenia podpisanego przez wiceministra spraw wewnętrznych gen. Bogusława Stachurę i ministra sprawiedliwości Sylwestra Zawadzkiego utworzono pięćdziesiąt dwa ośrodki odosobnienia w takich miejscowościach jak: Białołęka, Gołdap, Jaworze, Łowicz, Strzebielinek (miejsce internowania działaczy z centrali Solidarności) i Załęże ${ }^{24}$ do któ-

19 Rozmowa z M. Machem przeprowadzona przez Joannę Komperdę dnia 5 X 2009, własność Muzeum PRL w Krakowie.

20 Acta Cracoviensia tempore status belli 13 XII 1981 -1982, Komitet Oporu Społecznego Służby Zdrowia, s. 1.

${ }^{21}$ Małopolska była regionem, w którym w połowie grudnia 1981 r. strajkowało wiele zakładów. Do najważniejszych strajków, oprócz Huty im. Lenina w Nowej Hucie, doszło w na terenie Krakowa: w Miejskim Przedsiębiorstwie Komunikacji (13-15 XII), Przedsiębiorstwie „Montin” (14-16 XII), „,Telpodzie” (14-16 XII), , Armaturze (14 XII), CeBeA (14 XII) oraz w mniejszych ośrodkach: Odlewni Żelaza w Charsznicy (14 XII) i filii HiL w Bochni (13-15 XII). To ilustruje skalę zjawiska. Zob. W. Bukowski, dz. cyt., s. 9.

22 Pracował w Wytwórni Sprzętu Komunikacyjnego - Państwowych Zakładach Lotniczych w Krakowie, gdzie od września 1980 r. współtworzył struktury Solidarności. Pełnił funkcję przewodniczącego Komisji Wydziałowej Centrum Obróbczego WSK - PZL. 14 XII 1981 r. Roku, jako przewodniczący Komitetu Strajkowego, organizował strajk robotników WSK-PZL. Jego głównym polem działalności niezależnej była podziemna poligrafia. Od 1982 r. był drukarzem, organizatorem kolportażu, autorem tekstów, redaktorem wielu pism, m.in. ,Jesteśmy, będziemy...", ,"Miscellanea", ,"Serwis Informacyjny RKW/RKS”, ,"Hutnik" (od 1983 r.). Ponadto organizował kolportaż prasy niezależnej napływającej do Krakowa z całej Polski. Założył i prowadził kilka krakowskich bibliotek wydawnictw niezależnych, m.in. w WSK-PZL i w PAN. 5 XI 1982 r. został na kilka miesięcy powołany do służby wojskowej w Wojskowym Obozie Specjalnym w Czerwonym Borze. W ciagu swojej działalności opozycyjnej był wielokrotnie zatrzymywany i przesłuchiwany przez SB. (źródło: relacja nagrana w dniu 20 XI 2009 r.).

${ }^{23}$ Rozmowa z L. Jaranowskim przeprowadzona przez J. Komperdę dnia 20 XI 2009 r., własność: Muzeum PRL-u w Krakowie.

24 W. Roszkowski, Najnowsza historia Polski 1980-2002, Warszawa 2003, s. 49. 
rego trafiali działacze z Małopolski przebywający wcześniej w obozie w Wiśniczu Nowym. Terenowe jednostki Służby Bezpieczeństwa pierwsze rozkazy otrzymały już 12 grudnia ok. godz. $16.00^{25}$.

Internowania nie uniknęli także działacze opozycji z Krakowa. Waldemar Bukowski podawał, że w nocy z 12/13 grudnia 1981 r. zostało internowanych 94 opozycjonistów z Krakowa ${ }^{26}$, do końca 1981 r. liczba ta wzrosła do ok. 12027, a według Andrzeja Chwalby do 30 kwietnia 1982 r. liczba ta zwiększyła się do 326 osób ${ }^{28}$.

Taki los spotkał także J. Franczyka. Swoją sytuację z nocy 12/13 grudnia 1981 r. opisywał w słowach: „Położyłem się spać około 23.30 i była może 23.45, kiedy ktoś zapukał do drzwi. Wstałem i pytam:

- Kto tam?

- Milicja.

Więc ja zgodnie z wyuczoną przez czas działania w opozycji instrukcją mówię:

- Panowie proszę przyjść o szóstej rano. Wtedy panów wpuszczę, a teraz jest noc i nie ma szans.

- Ale to jest ważna sprawa, mamy nakaz.

- Proszę przyjść o szóstej rano.

- To wyważymy drzwi.

- To wyważcie.

Wtedy odeszli, ale czułem, że nie jest dobrze. Zrobiłem sobie kawy, rodzice się obudzili. Matka pyta mnie co się dzieje, ojciec też lekko podenerwowany. Mówię, że milicja była przed chwila, powiedzieli, że drzwi wyważą, ale poszli. Minęło może pół godziny kiedy znowu przyszli i powiedzieli, że muszę otworzyć, bo inaczej wyważą drzwi. Ojciec zaczął krzyczeć zdenerwowany, że temu, który wejdzie pierwszy łeb rozwali siekiera, co zresztą zostało dokładnie opisane przez jednego z oficerów, o czym mogłem się przekonać dzięki dokumentom otrzymanym z IPN. Przynieśli dużą łyżkę do ściągania opon samochodowych i pchnęli w drzwi, aż wyleciały. Pamiętając słowa ojca o siekierze, weszli z bronia, ale jak zobaczyli, że spokojnie siedzę w fotelu i popijam kawę, to broń opuścili. Wtedy podali mi kartkę, że jest stan wojenny i jestem internowany. Pożegnałem się z rodzicami, mówiąc im, że pewnie za kilka dni dowiedzą się, co się ze mną stało"29.

Opowieść J. Franczyka, który został internowany w Wiśniczu Nowym, obrazuje jak wyglądały pierwsze godziny stanu wojennego z perspektywy opozycjonisty. Wyczuwalna w nich atmosfera napięcia tylko podkreśla odwagę takich ludzi jak J. Franczyk. Nie mieli oni pojęcia, co ich może czekać, czego dowodzi ostatnie zdanie przytoczonej wypowiedzi, mimo, że starali się już wcześniej przygotować na wypadek internowania „zgodnie z wyuczoną przez czas działania w opozycji instrukcją". Moim zdaniem, strach internowanych i ich bliskich mógł potęgować także fakt, że wydarzenia, o których piszę, miały miejsce w okresie zimowym. W drugiej połowie grudnia $1981 \mathrm{r}$. temperatury sięgały kilkunastu stopni poniżej zera, a internowani i ich rodziny nie wiedzieli ani dokąd trafią, ani jakie warunki tam zastaną.

Działacze Solidarności, którym udało się uniknąć internowania, podjęli strajki w całej Małopolsce. Najważniejszy z nich miał miejsce w Hucie im. Lenina. Brało w nim udział ok. 7 tys.

25 Wykład Zdzisława Zblewskiego Utopia nad Wisła wygłoszony 13.01.2010.

26 W. Bukowski, dz. cyt., s. 9.

27 Kronika Krakowa, Warszawa 1996, s. 467.

28 A. Chwalba, dz. cyt., s. 408.

29 Moja Nowa Huta. 1949-2009 wystawa jubileuszowa, dz. cyt., s. 146. 
osób ${ }^{30}$, w sumie na dwóch zmianach strajkowało ok. 15 tys. ludzi. Po nieudanej próbie aresztowania przez oddział milicji działaczy $\mathrm{KRH}$ „S" przebywających na nocnym dyżurze w lokalu związkowym, Stanisław Handzlik wezwał do strajku okupacyjnego, bezterminowego. Strajk na zgniataczu rozpoczął się około 2.30 w nocy. Do rana 13 grudnia strajkowały już wszystkie wydziały konsultacyjne HiL.

O godz. 13.00 jego przedstawiciele spotkali się z kierownictwem Kombinatu HiL ${ }^{31}$, w celu podjęcia pierwszych rozmów na temat zaistniałej sytuacji. Od 15.00 zaczęła obowiązywać pierwsza uchwała Komitetu Strajkowego, którą podpisał jego przewodniczący Mieczysław Gil. Na jej mocy uprawnienia i obowiązki rozbitego Zarządu Regionu NSZZ Solidarność przejęła Komisja Robotnicza Hutników. Podkreślano, że decyzja ta obowiązuje aż do odwołania ${ }^{32}$.

Jeszcze tego samego dnia wieczorem M. Gil, przewodniczący Komitetu Strajkowego HiL, napisał list do rodzin uczestników strajku:

„Drodzy nasi najbliżsi, rodziny

Matki, Ojcowie, nasze dzieci.

Na ogłoszenie stanu wojennego Huta odpowiedziała strajkiem. Jest to odpowiedź na aresztowanie naszych działaczy. Ten strajk jest naszym związkowym, podstawowym ludzkim obowiązkiem, potwierdzonym przez Statut.

Chcieliśmy i chcemy porozumienia całego narodu. TO NIE MY ogłosiliśmy stan wojenny. Wszyscy wiemy, że sytuacja w kraju i mieście nie wymagała zastosowania takiego środka: nie było ani anarchii ani terroru. Społeczeństwo niezmiennie wykazywało wzorowe opanowanie i cierpliwość. (...) Zawiesza się działanie Związku Solidarność, który próbował kraj ratować. Pozostał nam tylko strajk jako ostatni środek protestu (...) Warunkiem porozumienia jest uznanie dalszego legalnego działania NSZZ SOLIDARNOŚĆ i bezpieczeństwo jego działaczy. Nie będzie współpracy i nie będzie możliwości porozumienia póki nie będziemy wszyscy razem z naszymi działaczami z całą Komisją Krajową włącznie. Zwolnienie wszystkich internowanych i zaprzestanie aresztowań to warunek podstawowy i nieodwołalny. Najbliżsi zwracamy się z apelem o SOLIDARNOŚĆ, wzajemną pomoc zajęcie się rodzinami nieobecnych, o spokój i godność w obliczu represji. NIE ZAPOMNIMY CZASU SOLIDARNOŚCI. Popełniliśmy błędy, ale wywalczyliśmy na krótko odsłonięcie prawdy o krzywdzie Ojczyzny i o źródłach jej siły. TRWA I BĘDZIE TRWAĆ. Już nigdy nie popadniemy w biernośći zakłamanie, nikt nie podpisuje hańbiących próśb o ułaskawienie. Bądźmy wierni sumieniu i przekonaniu cokolwiek się stanie.

13 grudnia 1981 za Komitet Strajkowy HiL godz. $18.30^{33 \prime \prime}$

M. Gil zaznaczał, że w grudniu 1981 r. nie było potrzeby wprowadzenia stanu wojennego. Przez wiele lat powtarzano argument, że jego ogłoszenie zapobiegło wkroczeniu wojsk ZSRR do Polski. Dziś już z całą pewnością możemy powiedzieć, że takie obawy nie były wówczas uzasadnione. 10 grudnia 1981 r. gen. Jaruzelski poinformował władze sowieckie o decyzji dotyczącej wprowadzenia stanu wojennego w Polsce i poprosił o gwarancję pomocy wojskowej, gdyby sytuacja w naszym kraju stała się krytyczna. Sowieci odmówili jej udzielenia ${ }^{34}$.

30 Nowa Huta - miasto pracy i walki, http://www.ipn.gov.pl/ftp/wystawy/nowa_huta/html/wstep.html\#stanwojenny 23.11.2011.

31 Tamże.

32 Dokument numer 3 [w:] W. Bukowski, dz. cyt., s. 41.

33 Dokument numer 2 [w:] W. Bukowski, dz. cyt., s. 40.

34 Stan wojenny. Ostatni atak systemu, Warszawa 2006, s. 7. 
List przewodniczącego Komitetu Strajkowego HiL miał na celu podniesienie na duchu zarówno strajkujących, jak ich rodziny, czy też najbliższych osób tych, którzy zostali internowani. Ich uwolnienie stało się podstawowym celem protestu. Zachęcano rodziny internowanych do wzajemnej pomocy. Domagano się również przywrócenia legalnego NSZZ Solidarność, którego działalność zawieszono. Odwoływano się do wzajemnej solidarności i pomocy robotników, deklarowano jakikolwiek brak współpracy z władzami. Uważano bowiem, że nadużyły one swoich uprawnień znacząco ograniczając wolność obywateli, których działania w ramach NSSZ Solidarność określały słowem ",terror". Podkreślano, że za obecną sytuację gospodarczą kraju, za pogłębiający się kryzys odpowiedzialne są tylko i wyłącznie władze państwowe; zaznaczano, że społeczeństwo próbowało się dostosować do warunków sprzed 13 grudnia $1981 \mathrm{r}$.

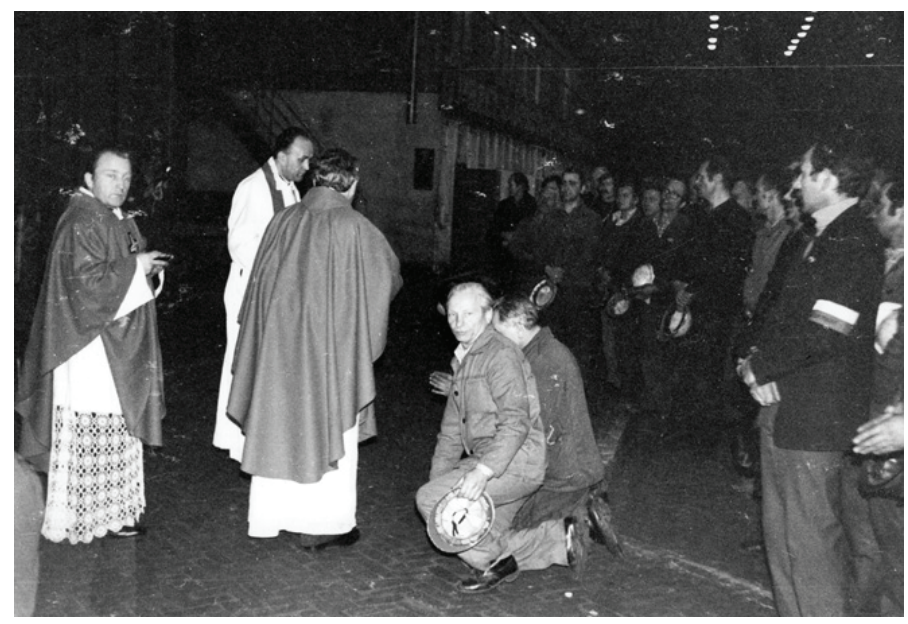

Msza św. w czasie strajku w Walcowni Blach Karoseryjnych Huty im. Lenina 13 grudnia 1981 r. odprawiana przez ks. Jana Bielańskiego i Józefa Bielańskiego; fot. Józef Fularz ${ }^{35}$. Zdjęcie można było zobaczyć na wystawie Nowa Huta 1949+ otwartej w dniach od 25 stycznia do 04 kwietnia 2012 roku w oddziale Muzeum Historycznego Miasta Krakowa - Dzieje Nowej Huty. Pochodzi $\mathrm{z}$ arch. Oddziału Instytutu Pamięci Narodowej w Krakowie.

\section{Kolejne DNi STRAJKU w HUCIE IM. Lenina}

14 grudnia o godz. 3.30 Komitet Strajkowy Hutników wydał Uchwałę Nr 3, w której M. Gil pytał „przeciwko komu ma być ta wojna”36. Twierdził, że Komitet Strajkowy HiL. „nie znajduje żadnego uzasadnienia dla wprowadzenia stanu wojennego w sytuacji braku zagrożenia zewnętrznego" ${ }^{\prime \prime 3}$. W drugim dniu strajku Komitet Strajkowy HiL nie zamierzał zatem podjąć żadnych rozmów z władza; był zdecydowany walczyć z milicjantami, gotowy do strajku głodowego. Jego celem było uwolnienie wszystkich internowanych dzień wcześniej. Niemniej w godzinach popołudniowych doszło do spotkania przedstawicieli Komitetu Strajkowego z przedstawicielem Komitetu Obrony Kraju w obecności dyrektora naczelnego Kombinatu HiL ${ }^{38}$.

\footnotetext{
24.11.2011.

36 W. Bukowski, dz. cyt., s. 42.

37 Tamże.

38 "Głos Nowej Huty" 1982, nr 1 (1303), s. 2.
}

${ }_{35}$ Nowa Huta - miasto pracy $i$ walki, http://www.ipn.gov.pl/ftp/wystawy/nowa_huta/html/plansza14d.html, 
Strajkujący chcieli, aby sytuacja w Kombinacie stała się znana szerszej opinii publicznej. 15 grudnia Komitet Strajkowy NSZZ Solidarność Małopolska wydał „Apel do Narodów Zjednoczonych"39, w którym podkreślał nielegalność działań polskich władz powołując się na art. 31 Konstytucji i nawoływał do pomocy rodakom; jego celem było zatem informowanie o ówczesnych wydarzeniach w Polsce w ogóle. Pamiętajmy, że w tym okresie trudno było kontaktować się z kimkolwiek z powodu cenzury korespondencji i zawieszenia połączeń telefonicznych. Trudno było także udać się na teren innego miasta. Ludzie mieli utrudniony dostęp do rzetelnych informacji z kraju.

Z inicjatywy studenta Politechniki Krakowskiej Stanisława Tyczyńskiego ${ }^{40}$ i Stanisława Handzlika ${ }^{41}$ uruchomiono w Kombinacie Radio Wolna Polska, które po kilku miesiącach zostało przekształcone w Radio Solidarność Małopolska. W grudniu 1981 r. nadawano „przede wszystkim komunikaty; było tam podkreślenie, że mówimy do Państwa ze skrawka wolnej Polski, czyli się znajdujemy tu w Kombinacie" ${ }^{\prime \prime 2}$. Miało ono zasięg ok. $5 \mathrm{~km}$, zatem obejmowało tylko część Nowej Huty, niemniej stało się jednym z nowohuckich symboli walki z nakazami władz centralnych. Dzięki emitowaniu pieśni patriotycznych (np. Legiony) podtrzymywało na duchu zmęczone i wystraszone całą sytuacją społeczeństwo najmłodszej dzielnicy Krakowa.

Tego samego dnia o godz. 16.00 podjęto ponowne rozmowy między przedstawicielami Komitetu Strajkowego a pełnomocnikiem Komitetu Obrony Kraju z jednostronnym ustaleniem terminu zakończenia strajku do godz. $18.00^{43}$. Strajkujący nie zaprzestali jednak swoich działań.

15 grudnia sytuacja pozostawała bardzo napięta. Atmosferę tego dnia oddają słowa jednego z anonimowych robotników z Nowej Huty: „Wszyscy strasznie się bali. Byliśmy zdecydowani na wszystko, nawet na śmierć. Ale nie było czym walczyć. Nikt nie zarządził. Kilkakrotnie powtarzane były alarmy, że już idą. Szturm rozpoczął się o pierwszej w nocy. Atak obwieściło wycie syren w całej Hucie. Utworzyliśmy krag"4. Cały czas przez megafon mówili do nas Hudaszek i Bortnowska. Stali na takich metalowych schodkach. Nie chcieli wejść do kręgu. Mówili, by nie stawiać oporu, skupić się razem, pilnować kolegów. Szczególnie Bortnowska podtrzymywała nas na duchu, żartowała, śmiała się, że czemu się tak boimy" ${ }^{\prime \prime 5}$.

A tak tamten dzień zapamiętała jedna z uczestniczek strajku w Kombinacie: „Z przodu hali ustawiono młodych, silnych ludzi, a dalej ciasno stanęła reszta, w środku kobiety. Żeby nas nie wydzierali pojedynczo. Staliśmy tak i śpiewaliśmy. Mijały godziny a nikt nie przychodzit. Napięcie i zdenerwowanie udzieliło się wszystkim. Było zimno. Wtedy ktoś powiedział, że nie ma sensu tak stać i żeby kobiety i goście weszli do dyspozytorni. Za chwilę przyszedł chłopak z innego wydziału i powiedział, że u nich już po wszystkim, że oni tak samo stali i gdy zomowcy kazali się rozejść, oni nie posłuchali. Potem wyciągnęli pierwszego i zaczęli bić. Wtedy ludzie poszli już sami"46.

Obydwie relacje oddają atmosferę ostatniego dnia strajku w HiL. Jego uczestnicy pozostawali w napięciu, obawiali się ataków milicjantów. Zdawano sobie sprawę, że w przeszłości służby

39 Dokument numer 9 [w:] W. Bukowski, dz. cyt., s. 44-45.

40 Jeden z założycieli Radia RMF FM.

${ }^{41}$ Wiceprzewodniczący Komisji Robotniczej Hutników, organizował okupacyjny strajk hutników w dniach 13 16 XII 1981 r., po którego pacyfikacji przebywał w ukryciu przez kilka miesięcy. W tym czasie współorganizował tajne struktury Solidarności, m.in. był jednym z sygnatariuszy dokumentów Regionalnej Komisji Wykonawczej Małopolska.

42 Rozmowa ze S. Handzlikiem przeprowadzona przez J. Komperdę dnia 2 IX 2009 r., własność Muzeum PRL w Krakowie.

43 "Głos Nowej Huty" 1982, nr 1 (1303) , s. 2.

44 Takie były zalecenia Komitetu Strajkowego HiL.

45 W stanie, Warszawa 1984, s. 14.

46 Tamże, s. 15. 
porządkowe strzelały do robotników ${ }^{47}$. Tym razem strajki obiegły całą Polskę, nie tylko poszczególne regiony kraju, jak w 1970 i 1976 r. Faktycznie tego samego dnia w kopalni Wujek śmierć poniosło siedmiu górników, a dwóch następnych zmarło po kilku dniach. Ich przelana krew stała się powodem manifestacji odbywających się potem szesnastego dnia każdego miesiąca, stała się też jednym z symboli stanu wojennego w Polsce - po raz kolejny w historii PRL ludzie zginęli z powodów politycznych. Obawiano się takiego przebiegu wydarzeń w Nowej Hucie, która stała się głównym bastionem Solidarności w południowej Polsce. Słowa robotnika, które przytoczyłem powyżej, mimo, że z całą pewnością były bardzo emocjonalne, potwierdzaja, że zakładano, iż w Kombinacie mogą pojawić się ofiary śmiertelne ${ }^{48}$.

16 grudnia o godz. 2.00 podjęto atak na strajkujących. W obliczu ataku dziesięciu czołgów T 54, które staranowały mur wokół bramy Kombinatu oraz ponad 2 tys. żołnierzy i 2150 funkcjonariuszy $\mathrm{ZOMO}^{49}$, strajkujący postanowili zaprzestać swojego działania.

Jak wyglądał przebieg pacyfikacji HiL? Oddajmy głos jej dwóm uczestnikom. M. Mach, który opowiedział o zachowaniu mundurowych: „U nas nie było z ich strony ani przemocy ani bicia. To znaczy była agresja w takim sensie zastraszenia. Takie krzyki, wrzaski, jakieś pohukiwania. Natomiast bardzo bali się ponieważ chyba poszła jakaś plotka, że my się będziemy bronić w związku z tym bardzo bali się żeby nie zrzucać różnych rzeczy itd. Więc tylko tyle - wrzeszczeli, żeby tam, powiedzmy, zachować spokój" ${ }^{\prime 50}$.

Nie było jednak pełnej zgodności, co do kwestii jak należy się zachować w przypadku interwencji milicjantów. Wspomniany już S. Handzlik opowiadał o tym po latach: „Spieraliśmy się o to jaką formułę przyjąć. Czy opór czynny - uzbroić się w cokolwiek ${ }^{51} \mathrm{i}$ iść przeciwko czołgom, przeciwko karabinom maszynowym itd. albo uznać, że to nie jest jeszcze koniec świata, nie jest to koniec Solidarności, że należy to przeżyć jak najmniejszymi kosztami, najmniejszymi ofiarami. Zwyciężył na szczęście ten wariant drugi oporu biernego, który wytłumaczyliśmy na czym ma polegać" 52 .

Wydaje się, że była to mądra i odpowiedzialna decyzja, co potwierdzali wyżej cytowani strajkujący. Dzięki niej, w przeciwieństwie do „Wujka”, obyło się bez ofiar śmiertelnych.

16 XII zakończył się pewien etap konfrontacji władzy z jej przeciwnikami. Strajkujący w Kombinacie ponieśli jednak pewne konsekwencje - dyscyplinarnie zwolniono 2 tys. robotników HiL. Kolejnego dnia doszło do manifestacji w centrum Krakowa. W Kościele Mariackim odbyła się msza św. upamiętniająca rocznicę wydarzeń Grudnia'70 73 . Pod Kościołem Mariackim manifestanci skandowali: „Wrona skona" i „Jaruzelski zdrajca”. Zostali oni przepędzeni przez armatki wodne, które działały mimo kilkunastu stopni mrozu ${ }^{54}$. Nowohuccy działacze Solidarności musieli zmienić swoje działania. Nadchodzące Święta Bożego Narodzenia nie były dla nich szczęśliwe. Wielu pracowników największego zakładu pracy w Nowej Hucie straciło źródło utrzymania, a ich przyszłość stawała się coraz bardziej niepewna.

${ }^{47}$ Wydaje się, że wspomnienie grudnia'70 i zwłaszcza czerwca'76 były w świadomości robotników.

48 W stanie, dz. cyt., s. 14.

49 A. Chwalba, dz. cyt, s. 411.

${ }^{50}$ Rozmowa z M. Machem przeprowadzona przez J. Komperdę dnia 5 X 2009 r., własność Muzeum PRL w Krakowie.

${ }^{51}$ Stanisław Handzlik podkreślał, że młodzi ludzie ze Zgniatacza, gdzie znajdowało się centrum strajkowe, przygotowywali koktajle Mołotowa, by bronić swojego skrawka wolności przed szarżującymi pojazdami milicji i wojska.

${ }_{52}$ Rozmowa ze S. Handzlikiem, dz. cyt.

53 A. Dudek, T. Marszałkowski, Walki uliczne w PRL 1956-1989, Kraków 1992, s. 176.

54 A. Chwalba, dz. cyt, s. 411. 
Kolejne miesiące udowodniły opozycyjny charakter Nowej Huty. Mieszkańcy najmłodszej dzielnicy Krakowa podjęli zarówno opór bierny jak i czynny. Opór bierny przejawiał się w bojkotowaniu oficjalnej prasy czy wieczornego dziennika zakłamujących rzeczywistość, malowaniu różnych haseł na budynkach ${ }^{55}$, tworzeniu i kolportażu nielegalnych ulotek i prasy. Jak wynika z dokumentów krakowskiego oddziału Instytutu Pamięci Narodowej w Nowej Hucie ukazywały się pisma podziemne: „,Obserwator Wojenny" sygnowany przez MKS Nowa Huta, „Solidarność Zwycięży" i „Montinowiec" sygnowane przez porozumienie prasowe "Solidarność Zwycięży” przy MKS Nowa Huta, „Hutnik” wydawany przez członków NSZZ Solidarność HiL ${ }^{56}$.

Od czerwca 1982 r. w Nowej Hucie dochodziło do największych manifestacji patriotycznych w Krakowie, które bardzo często kończyły się wielogodzinnymi walkami ulicznymi. Ich konsekwencjami były aresztowani ${ }^{57}$, liczne obrażenia manifestantó ${ }^{58}$, zniszczone budynki użyteczności publicznej, jak np. IV Komisariat MO w Bieńczycach, który ucierpiał 13 czerwca $1982 \mathrm{r}$. w skutek obrzucenia go kamieniami ${ }^{59}$.

Zajścia uliczne miały miejsce najczęściej trzynastego (miesięcznica wprowadzenia stanu wojennego) i szesnastego (miesięcznica pacyfikacji Kopalni Węgla Kamiennego „Wujek”) dnia miesiąca. Do demonstracji dochodziło też z okazji świąt narodowych nie uznawanych przez władze komunistyczne (3 majai11 listopada) oraz rocznic związanych z Solidarnością. Do szczególnie zaciętych walk doszło 31 sierpnia 1982 r. w drugą rocznicę podpisania porozumień sierpniowych w Gdańsku. Według Antoniego Dudka i Tomasza Marszałkowskiego manifestowano wówczas w 66 miastach na terenie 34 z ówczesnych 49 województw ${ }^{60}$. Najtragiczniejsze wydarzenia mia-

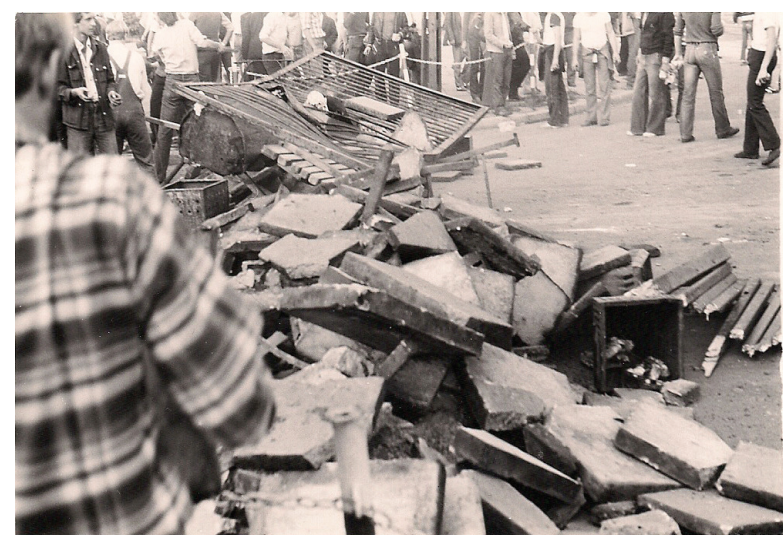
ły miejsce w Lublinie - 3 osoby zapłaciły życiem za udział w zamieszkach. Również w Krakowie i Nowej Hucie odbyły się wielogodzinne walki uliczne powodujące znaczne zniszczenia. Zdjęcie obok zostało wykonane przez jednego z uczestników demonstracji w Nowej Hucie. ${ }^{61}$

Niestety zdarzały się przypadki ofiar śmiertelnych. W kwietniu 1982 r. doszło do tragicznego w skutkach zdarzenia. Pobity przez ZOMO 22-letni robotnik HiL Andrzej Szewczyk przez siedem tygodni walczył o życie lecz nie odzyskał już nigdy przytomności. Został skatowany, ponieważ wracał do domu po godzinie milicyjnej. Zmarł na początku czerwca, a jego ojciec z goryczą mówił: „,wal-

55 IPN Kr 210/121, Sekretariat Wojewódzkiego Komitetu Obrony Kraków. Zbiór protokołów z posiedzeń WKO wraz z materiałami stanowiacymi przedmiot obrad (16.03-26.04.1982), k. 52. Znajdujemy tam informacje o hasłach malowanych w lutym 1982 r. na Osiedlach: Stalowym, Hutniczym, Ogrodowym, Centrum „A”, Kolorowym, Centrum „B” i Centrum „C,.

56 IPN Kr 056/98/2/DVD/1, Plany i sprawozdania Wojewódzkiego Urzędu Spraw Wewnętrznych w Krakowie, k. 41-42.

${ }_{57}$ Np. za udział w demonstracjach 31 sierpnia 1982 r. w Nowej Hucie i Śródmieściu zatrzymano 259 osób. Zob. A. Dudek, T. Marszałkowski, dz. cyt., s. 195.

58 Zob. Acta Medica Cracoviensia Tempore Status Belli 13 XII 1981 - 1982.

59 A. Dudek, T. Marszałkowski, dz. cyt., s. 188.

60 Tamże, s. 190.

6131 sierpnia 1982 r. w Nowej Hucie. Własność Zdzisława Szczupaka. 
czyłem na froncie, otrzymałem wiele odznaczeń, w tym krzyż Virtuti Militari, a mój ostatni krzyż to ten-na grobie mego syna" ${ }^{2}$. Szewczyk był pierwszą ofiarą śmiertelną stanu wojennego w Krakowie.

W październiku 1982 r. zginął 20-letni Bogdan Włosik, a w maju 1983 r. 29-letni Ryszard Smagur $^{63}$. Ich pogrzeby stawały się kolejnymi manifestacjami sprzeciwu przeciw sytuacji w kraju, a brały w nich udział tysiące ludzi.

Kilka dni po zabójstwie Włosika „Gazeta Krakowska” w artykule Absolutna większość mieszkańców Nowej Huty nie chce mieć nic wspólnego z zamieszkami informowała, że zaostrzono dyscyplinę w hotelach robotniczych oraz w internatach, zwracając szczególną uwagę na organizację zajęć dla młodzieży ${ }^{64}$. Artykuł miał na celu m.in. przedstawić, że przeciwnicy systemu manifestujący na ulicach są w zdecydowanej mniejszości, a większość nowohucian pragnie spokoju i nie chce aby w przyszłości powtarzały się zajścia uliczne.

Nowa Huta pozostała miastem niepokornym, buntowniczym nie tylko do odwołania stanu wojennego, ale aż do końca lat osiemdziesiątych $X X$ wieku ${ }^{65}$.

Opozycyjny charakter, interesującej nas dzielnicy Krakowa, podkreśla Marek Lasota, dyrektor IPN w Krakowie, który w filmie Dymy nad Arka Pana $a^{66}$ mówit: „W latach 80-tych to życie solidarnościowe, ta walka, fizyczna także, bo to była walka fizyczna, nie miejmy co do tego złudzeń, koncentruje się przede wszystkim w Nowej Hucie i to jest niezwykle symboliczne zjawisko" ${ }^{\prime \prime 7}$.

Dla zrozumienia tego stwierdzenia należy się cofnąć do końca lat 40-tych i początku lat 50-tych, kiedy Nowa Huta była budowana. W myśl założeń jej twórców miała stać się wzorowym miastem socjalistycznym będącym symbolem nowego systemu politycznego Polski. W rzeczywistości jednak, najmłodsza dzielnica Krakowa, przez cały okres istnienia PRL, stawiała opór owemu systemowi politycznemu w naszym kraju. Strajk w HiL, w pierwszych dniach stanu wojennego, dowiódł tego dobitnie. Przyszłość pokazała, że nie był to ostatni taki przypadek. ${ }^{68}$

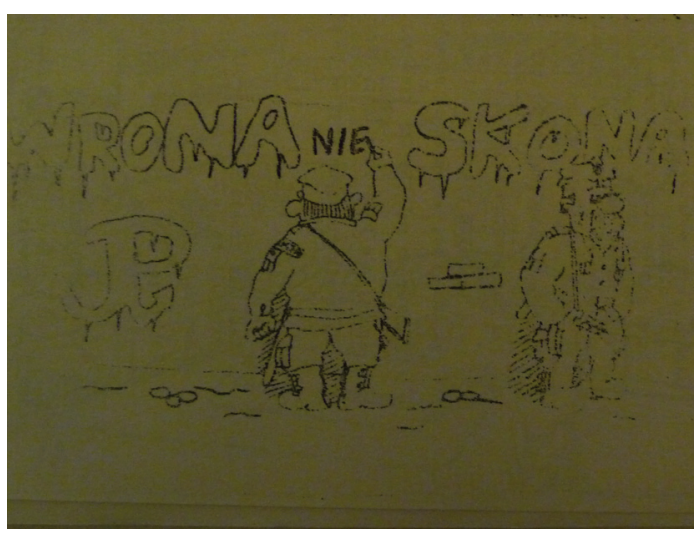

\section{Bibliografia}

Acta Medica Cracoviensia Tempore Status Belli 13 XII 1981 - 1982, Komitet Oporu Społecznego Służby Zdrowia Bukowski W., Solidarność Małopolska w Podziemiu, Kraków 1991.

Chwalba A., Dzieje Krakowa. Kraków w latach 1945-1989. t. 6., Kraków 2004.

Dudek A., Marszałkowski T., Walki uliczne w PRL 1956-1989, Kraków 1992.

\footnotetext{
${ }^{62}$ Migawki-Andrzej Szewczyk, „Solidarność Zwycięży” 1982, nr 4 z 27.06.1982, s. 2.

${ }_{63} \mathrm{http}: / /$ www.bialo-czerwona.pl/stan_wojenny/ofiary.htm, 26.04.2012.

64 Absolutna większość mieszkańców Nowwej Huty nie chce mieć nic wspólnego z zamieszkami, „Gazeta Krakowska” 1982, nr 183 (11519) z 22-24.10.1982, s. 1-2.

65 R. Kasprzycki, Opozycja polityczna w Krakowie w latach 1988-1989, Kraków 2003, s. 34-44.

${ }_{66}$ Film wyprodukowany przez MH.MEDIA.PL dla TVP Kraków w 2009 r. Scenariusz i realizacja: Miłosz Horodyski. Tytuł nawiązuje do walk ulicznych w okolicach bieńczyckiego Kościoła Matki Boskiej Królowej Polski zwanej potocznie Arką Pana, które miały miejsce przez całą dekadę lat 80-tych.

67 Tamże, fragment 4:28-4:42.

68 Satyra stanu wojennego, Lublin 1983.
} 
Dudek A., Zblewski Z., Utopia nad Wisła. Historia Peerelu, Warszawa - Bielsko-Biała 2008.

„Gazeta Krakowska” z lat 1981-1983.

Gliksman A., Solidarność Małopolska. Kalendarium 1980-2005, Kraków 2005.

„Głos Nowej Huty" z lat 1981-1983.

IPN Kr 056/98/2/DVD/1, Plany i sprawozdania Wojewódzkiego Urzędu Spraw Wewnętrznych w Krakowie.

IPN Kr 210/121, Sekretariat Wojewódzkiego Komitetu Obrony Kraków. Zbiór protokołów z posiedzeń WKO wraz z materiałami stanowiacymi przedmiot obrad (16.03-26.04.1982)

Kasprzycki R., Opozycja polityczna w Krakowie w latach 1988-1989, Kraków 2003

Kronika Krakowa, Warszawa 1996.

Moja Nowa Huta. 1949-2009 wystawa jubileuszowa, Muzeum Historyczne Miasta Krakowa, Kraków 2009.

Roszkowski W., Najnowsza historia Polski 1980-2002, Warszawa 2003,

Satyra stanu wojennego, Lublin 1983.

„Solidarność Zwycięży”, 1982-1983.

Stan wojenny. Ostatni atak systemu, Warszawa 2006.

W stanie, Karta, Warszawa 1984.

Zabłocki W., Stan wojenny w Małopolsce, Kraków 1994.

\section{Netografia}

Nowa Huta - miasto pracy $i$ walki, http://www.ipn.gov.pl/ftp/wystawy/nowa_huta/html/wstep.html\#stanwojenny 23.11.2011.

Nowa Huta - miasto pracy i walki, http://www.ipn.gov.pl/ftp/wystawy/nowa_huta/html/plansza14d.html, 24.11.2011.

http://www.jakiaparat.pl/najmlodsza_siostra_krakowa_druga_czesc_wystawy_plenerowej_poswieconej_nowej_hucie,1242423416,1, 26.04.2012.

http://www.bialo-czerwona.pl/stan_wojenny/ofiary.htm. 26.04.2012.

http://histmag.org/?id=6200, 27.04.2012.

\section{Filmografia}

Dymy nad Arką Pana, wyprodukowany przez MH.MEDIA.PL dla TVP Kraków w 2009 r. Scenariusz i realizacja: Miłosz Horodyski.

\section{ZdJęCIE ZE ZBIORÓW PRYWATNYCH ZDZiSŁaWA SZCZupaKa.}

\section{WYWIADY}

Rozmowa z L. Jaranowskim przeprowadzona przez J. Komperdę dnia 20.11.2009, własność: Muzeum PRL-u w Krakowie. Rozmowa ze S. Handzlikiem przeprowadzona przez J. Komperdę dnia 2.09.2009, własność Muzeum PRL w Krakowie. Rozmowa z M. Machem przeprowadzona przez J. Komperdę dnia 5.102009, własność Muzeum PRL w Krakowie.

\section{STRESZCZENIE}

Temat artykułu ma związek z trzydziestą rocznicą ogłoszenia stanu wojennego w Polsce 13 grudnia 1981 r. przez gen. Wojciecha Jaruzelskiego. Dotyczy jednego z największych miejsc oporu w kraju - Nowej Huty. Przedstawiłem jak wyglądało aresztowanie nowohuckiego działacza opozycyjnego w nocy z 12/13 grudnia 1981 r. Przybliżyłem przebieg strajku w największym zakładzie pracy w Krakowie - w Hucie im. Lenina w Nowej Hucie oraz jego pacyfikację.

Słowa kluczowe: Stan wojenny, strajk, Nowa Huta, pacyfikacja, internowanie, opozycja.

\section{First days of Polish Martial Law in Nowa Huta}

\section{Summary}

My paper is related to the thirtieth anniversary of the imposition of martial law in Poland on 13 December 1981. It focuses on Nowa Huta, a large borough in Cracow which mounted strong resistance to Jaruzelski's decision. I first discuss the way Nowa Huta's opposition activists were interned on the night of 12/13 December 1981 to later describe the details of the strike and its ultimate pacification.

Key words: Martial law, Nowa Huta, pacification, internment, opposition activists. 